\title{
Niewidoma kobieta, niewidoma pisarka. Tożsamości Jadwigi Stańczakowej
}

\begin{abstract}
Monika, Niewidoma kobieta, niewidoma pisarka. Tożsamości Jadwigi Stańczakowej [Blind woman, blind writer. Identities of Jadwiga Stańczakowa]. „Przestrzenie Teorii” 34. Poznań 2020, Adam Mickiewicz University Press, pp. 307-323. ISSN 1644-6763. DOI 10.14746/pt.2020.34.14.

The article concerns Jadwiga Stańczakowa, a blind journalist and writer, and friend of Miron Białoszewski. The author analyses Stańczakowa's writing as an independent literary phenomenon deserving its own interpretation. Drawing on autobiographical and autoethnographic work by Maria Reimann, who is also an author with a disability, the author observes the emancipatory meaning of blindness. The text present three identities of Jadwiga Stańczakowa. First, the author shows her as a woman and asks if her blindness affected her femininity and sexuality. Secondly, the author interprets fragments of texts written by Stańczakowa during depression. Finally, she describes the writer's identity, the most autonomous, although they all depend on Białoszewski.
\end{abstract}

KEYWORDS: Stańczakowa, blindness, disability studies, autoethnography

Niniejszy tekst zrodził się z zainteresowania twórczością i postacią Jadwigi Stańczakowej - niewidomej pisarki, której nazwisko najczęściej bywa przywoływane w parze z Mironem Białoszewskim. Za sprawa filmu Pare osób, maty czas ${ }^{1}$ oraz publikacji Dziennika we dwoje i Haiku ${ }^{2}$ Stańczakowa została przypomniana i zyskała szansę - wciąż nie do końca wykorzystana na uzyskanie autonomii od swego literackiego mistrza ${ }^{3}$. Nie sposób zupełnie odseparować autorkę Ślepaka od Białoszewskiego, byłoby to zreszta wbrew rzeczywistym splotom biografii i dzieł obojga twórców. Chodzi jednak o traktowanie książek Stańczakowej jako utworów własnych, osobnych i wartych uwagi nie ze względu na wpływy mentora i czynione przez niego korekty.

${ }^{1}$ Parę osób, mały czas, reż. A. Barański, 2005. O filmie - jako „intrygującej adaptacji diariusza Stańczakowej” - pisał Adam Poprawa. Zob. tegoż, Posłowie, [w:] J. Stańczakowa, Dziennik we dwoje, Wrocław 2015, s. 434-443.

${ }^{2}$ Obie książki wydało wrocławskie wydawnictwo Warstwy: J. Stańczakowa, Dziennik we dwoje, Wrocław 2015; tejże, Haiku, Wrocław 2015.

${ }^{3}$ Zob. Stańczakowa sama i z Mironem [skrócony zapis rozmowy Anny Sobolewskiej, Justyny Sobolewskiej, Joanny Mueller-Liczner i Elizy Kąckiej], <https://kulturaliberalna. pl/2015/09/08/stanczakowa-sama-i-z-mironem-skrocony-zapis-rozmowy/> [dostęp: 2.06.2020]. Warto także odnotować dwa ważne teksty popularyzujące sylwetkę Stańczakowej: A. Kopkiewicz, Sprawy babskie i ślepackie, „Dwutygodnik” 2015, nr 11 (172), <https://www.dwutygodnik. com/artykul/6240-sprawy-babskie-i-slepackie.html> [dostęp: 2.06.2020]; T. Sobolewski, Jadwiga Stańczakowa, pisarka, „Wysokie Obcasy” (dodatek do „Gazety Wyborczej”), 28.01.2006, nr 4, <https://www.wysokieobcasy.pl/wysokie-obcasy/1,96856,3132212.html> [dostęp: 2.06.2020]. 
„Inspirująca rola pisarza nie podlega dyskusji” - zauważał Adam Poprawa, ale dodawał: „Należy przecież oddać sprawiedliwość autorce. Czym innym jest bowiem naśladownictwo, czym innym wypracowywanie własnej oryginalności z wykorzystaniem (owszem, podziwianego) stylu cudzego. Czym innym jest wzorowanie się na kimś, czym innym zaś już w pełni własny talent, umożliwiający usłyszenie i estetyczne spożytkowanie odebranych wypowiedzi"4. Tatiana Czerska, badająca niuanse niesymetrycznego związku Stańczakowej i Białoszewskiego, sformułowała dobitnie brzmiące stanowisko: „Myślę, że pora, aby twórczość Stańczakowej zacząć traktować jako samoistne zjawisko" ${ }^{5}$. Podzielając powyższe sądy, dostrzegam jednocześnie, że systematycznie przyrasta naukowych wypowiedzi o Stańczakowej, których autorki i autorzy wielokierunkowo badaja jej teksty ${ }^{6}$. Sposób lektury wydaje mi się obecnie podstawowym problemem: jak czytać poezję i prozę Stańczakowej, zważywszy że ich głównym umocowaniem jest ślepota zarówno autorki, jak i podmiotu jej tekstów? Inspiracji można szukać w nurcie disability studies ${ }^{7}$, które ostatnio coraz śmielej wkraczają w przestrzeń polskich badań, również literaturoznawczych ${ }^{8}$. Widziane w tej perspektywie utwory Stańczakowej ujawniają tożsamościowy i emancypacyjny charakter podmiotu, zdolnego uczynić ze swej ślepoty atut i oś twórczości. Używane przez pisarkę autodefinicje - niewidoma, ślepa, ślepak - pozwalają dostrzec stopniową akceptację siebie jako osoby z dysfunkcja, którą się oswaja, opisuje i której ograniczenia nieustannie się przekracza, właściwie aż do zrównania statusu podmiotu niewidzącego i widzącego ${ }^{9}$.

${ }^{4}$ A. Poprawa, dz. cyt., s. 425.

${ }^{5}$ T. Czerska, Dzienniki podwójne, czyli o kanibalizmie w diarystyce (Michait i Jelena Buthakowowie, Jadwiga Stańczakowa i Miron Białoszewski), [w:] tejże, Diarystki: tekst i egzystencja, Szczecin 2018, s. 142.

${ }^{6}$ Poza już przywoływanymi zob. A. Frania, „Nie widzę i opisuję”. Refleksje o twórczości Jadwigi Stańczakowej, „Inter-. Literatura - Krytyka - Kultura” 2018, nr 317, <https://pismointer.wordpress.com/numery-archiwalne/nr-317-2018/arkadiusz-frania-nie-widze-i-opisuje-refleksje-o-wierszach-jadwigi-stanczakowej/> [dostęp: 2.06.2020]; M. Ładoń, „Ćwiczę widzenie”. O twórczości Jadwigi Stańczakowej, „Poznańskie Studia Polonistyczne”. Seria Literacka 32 (52), Poznań 2018. Wybrany przeze mnie model lektury nie wyklucza oczywiście możliwości innych interpretacji, choćby takich, które wychodząc od porównania poetyki tekstów Stańczakowej i tekstów Białoszewskiego, zarysują ścieżkę wypracowania przez pisarkę niezależnego stylu.

${ }^{7} \mathrm{O}$ modelach niepełnosprawności zob. w artykule Magdaleny Zdrodowskiej, Między aktywizmem a akademia. Studia nad niepetnosprawnościa, „Teksty Drugie” 2016, nr 5. Zob. także M. Zdanowska, Nie-złe upośledzenie, „Znak” 2017, nr 740.

${ }^{8}$ Zob. tematyczne numery czasopism: „Czas Kultury” 2019, nr 4 (zwłaszcza teksty Arlety Galant i Moniki Świerkosz) oraz „Fragile” 2017, nr 1 (przede wszystkim teksty Joanny Hańderek, Miłosza Markiewicza, Alicji Fidowicz).

${ }^{9}$ Nie rozwijam w tym miejscu tych wątków, ponieważ możliwości, jakie dają studia nad niepełnosprawnościami, skrzyżowane z badaniami tyflologicznymi oraz kategorią świadka, 
Drugim bodźcem powstania tego artykułu była lektura niedawno opublikowanej książki Marii Reimann Nie przywitam się z państwem na ulicy. Szkic o doświadczeniu niepetnosprawności $i^{10}$. Napisana przez antropolożkę kultury pozycja ma charakter autoetnografii i właśnie zwrot ku sobie wydaje mi się w niej najbardziej interesujący, autorka jest bowiem osobą niedowidząca. Samoświadomość Reimann powoduje, że badaczka dostarcza ciekawego klucza do zrozumienia przestrzeni osób z niepełnosprawnościami: nie tylko prezentuje rozmowy z kobietami urodzonymi z zespołem Turnera, ale lokuje je w pryzmacie własnego doświadczenia życia z niepełnosprawnością. Występuje w książce w podwójnej roli: jest badaczką i jednocześnie przedmiotem badań, a jej autobiografia nadaje całości specyficzne ramy dopełnione empatią zaangażowaniem i zrozumieniem dla zjawisk, o których pisze $^{11}$. Reimann, wychodząc od rozróżnienia na niesprawność (impairment) i niepełnosprawność (disability), stawia przed sobą i czytelnikami następujące pytania:

[...] kiedy i jak powstaje niepełnosprawność? Czy urodziłam się niepełnosprawna? Czy stałam się niepełnosprawna, kiedy jako szesnastolatka stanęłam przed komisją lekarską ZUS i dostałam orzeczenie o ,całkowitej niezdolności do pracy” ze względu na uszkodzenie narządu wzroku? Czy jestem niepełnosprawna, chociaż pracuję, wychowuję dziecko, jeżdżę na rowerze, podróżuję? A może tylko bywam niepełnosprawna, kiedy nie mogę prowadzić auta, nie widzę świateł po drugiej stronie ulicy albo napisów w kinie? [...] czy ja sama definiuję się jako osoba niepełnosprawna? Niedowidząca - tak, ale czy niepełnosprawna? ${ }^{12}$

Książka Reimann i zadawane przez nią pytania, jak te powyższe, stanowią dla tekstów Stańczakowej nieoczekiwaną i interesującą ramę. Niedowidzenie - jako element zbliżający obie piszacce - nie jest jedyną wspólną cecha, ale też nie zamierzam punktów wspólnych demonizować i tropić z przesadna aktywnościa, mam bowiem również świadomość głębokich różnic dzielących Reimann i Stańczakową. Mamy wszak do czynienia z kobietami w innym wieku i żyjącymi w innych czasach. Stańczakowa traciła wzrok stopniowo, od lat młodzieńczych, ale właściwie dopiero na początku lat pięćdziesiątych weszła w mrok niewidzenia. W niniejszym tekście interesować mnie będzie jeszcze późniejszy czas, czas narodzin Stańczakowej

interesowały mnie w innym tekście poświęconym Stańczakowej: Na gruzach widzenia. O prozie Jadwigi Stańczakowej, „Teksty Drugie” 2021, nr 1 [w druku].

${ }^{10}$ M. Reimann, Nie przywitam się z państwem na ulicy. Szkic o doświadczeniu niepetnosprawności, Wołowiec 2019.

${ }^{11} \mathrm{Na}$ temat autoetnografii zob. np. A. Kacperczyk, Autoetnografia-technika, metoda, nowy paradygmat? O metodologicznym statusie autoetnografii, „Przegląd Socjologii Jakościowej” 2004, nr 10.

${ }^{12}$ M. Reimann, dz. cyt., s. 17-18. 
pisarki, której poezja i proza noszą wyraźny odcisk ślepoty. W tym sensie autobiograficzny zwrot wydaje mi się - mimo wielu odmienności - u Stańczakowej i Reimann gestem podobnym. Stańczakowa nie używała oczywiście terminu „niepełnosprawność” ${ }^{13}$, ale - wyraźnie zachęcana przez Białoszewskiego - określała swoją tożsamość jako osoba niewidoma, ślepa czy ślepak ${ }^{14}$. Można przypuszczać, że również aktywność życiowa Stańczakowej, zbliżona do doświadczeń wymienianych przez Reimann, stawiałaby pod znakiem zapytania przydatność „niepełnosprawności” jako kategorii ją opisującej i prowadziłaby do podobnych pytań, jak przytoczone wyżej. Stańczakowa bywała niepełnosprawna wówczas, gdy napotykała na bariery i wykluczenia lub gdy oko widzącego ustanawiało ją w roli osoby z niepełnosprawnościa. "Nie lubię potykać się o swoja ślepotę"15, pisała z rozgoryczeniem w sytuacji, kiedy dysfunkcja okazywała się siłą wyłączająca ją z udziału w czymś dla niej ważnym. Z kolei będąc w centrum słynnych „wtorków Białoszewskiego”, wyczulona na przepływ ludzi obok siebie, odnotowywała związany z tym spadek własnego nastroju: „Chwilami smętnieję, jak to bywa niewidzącemu pośród widzących"16.

To, co u Stańczakowej jest poetyckie, wspomnieniowe czy diarystyczne, u Reimann jest dyskursywne, staje się auto/interpretacja. Reimann otwarcie pisze, że „niemożliwe jest stworzenie spójnej narracji o doświadczeniu życia z chorobą przewlekłą czy niepełnosprawnościa”" ${ }^{17}$, mając na myśli sprzeczne opowieści o sobie, z których złożyła własną książkę, ale jednocześnie nie sposób nie zauważyć, że to zdanie idealnie przystaje do wielogatunkowej narracji Stańczakowej na własny temat. Obie doświadczają tych samych emocji i podobnie podchodza do swojego nie(do)widzenia: traktuja je na zmianę z otwartością, lękiem i wstydem; wymagają wsparcia i zrozumienia w tym samym stopniu, w jakim zabiegają o poczucie wolności. „Wszystko jest tak, jak mówię, i zupełnie odwrotnie, każdej historii, jaką o sobie opowiem, mogę przeciwstawić inna, równie prawdziwa"18 - czytam u Reimann, a brzmi jak u Stańczakowej. Autoetnograficzne przedsięwzięcie prowadzi Marię Reimann do ważnej pointy:

${ }^{13}$ Definicja słowa została przyjęta przez Światową Organizację Zdrowia w 1980 roku. W Polsce termin został użyty i zdefiniowany w Ustawie z dnia 27 sierpnia 1997 roku o rehabilitacji zdrowotnej i społecznej oraz zatrudnianiu osób niepełnosprawnych (Dz.U. 1997 nr 123 poz. 776), <http://prawo.sejm.gov.pl/isap.nsf/DocDetails.xsp?id=WDU19971230776> [dostęp: 2.06.2020].

${ }^{14}$ Dwóch spośród tych terminów użyła jako tytułów książek - Niewidoma (debiut poetycki) oraz Ślepak (pierwszy tom prozy).

${ }^{15}$ J. Stańczakowa, Dziennik we dwoje..., s. 102.

${ }_{16}$ Tamże, s. 85.

${ }^{17}$ M. Reimann, dz. cyt., s. 151.

18 Tamże, s. 152. 
Niepełnosprawność jest tożsamościa, przed która próbowałam na różne sposoby uciec, bo wydawała mi się nieatrakcyjna. Czasem przerażająca, czasem ośmieszająca. Teraz [...] mogę spojrzeć na nią inaczej. Zobaczyć w niej jedną z wielu moich tożsamości, czasem bardziej, czasem mniej istotna, i zamiast się jej wstydzić, bać, żartować z niej, walczyć z nią, naprawdę się nią zaciekawić ${ }^{19}$.

Taki emancypacyjny potencjał ślepoty chcę opisać u Stańczakowej, przyglądając się tożsamościom konstruowanym w jej tekstach. Kolejne autodefinicje stanowią u poetki etapy schodzenia w głąb siebie: w ciemność własnego niewidzenia i jądro siebie rozumianej jako osoba niewidoma. Przekonana o ważności dzieła Stańczakowej - dzieła samoistnego, niezależnego od mironologicznych kontekstów - zakładam, że można w jego ramach, jak również w wariancie losu, odnaleźć ślady ewolucyjnego podejścia do określania siebie jako kobiety i pisarki niewidomej.

\section{„Kobieta niewidoma w niemłodym wieku" 20}

Sposób autoprezentacji w słowie odautorskim zamieszczonym w poetyckim debiucie książkowym Stańczakowej kieruje uwagę na kobiecość bohaterki. Istotnie, jedna z ważniejszych przestrzeni w jej wierszach jest na poły fantasmagoryczny salon, w którym bohaterka liryczna zestawia kolory sukien „na ślepo”, na prawach wyobraźni i wspomnień, decydujących o obecnym odczuciu odcieni - niewidzianych nigdy lub wyblakłych w pamięci kobiety. Takich wierszy jest w tomikach Stańczakowej naprawdę dużo i przekonuja, jak ta kobieca strona życia była dla niej ważna ${ }^{21}$. Na podobny trop naprowadzają zapisy dziennikowe, w których wielokrotnie powracaja opisy sukienek, farbowania włosów, dobierania strojów przed wyjściem, a lustrem, zwykle kapryśnym, jest oko Białoszewskiego. Kamil Pietrowiak, autor etnograficznego studium niewidzenia, przekonuje, że „to właśnie wygląd zewnętrzny - poddawany ciąłej ocenie i klasyfikacji - okazuje się niezbywalnym składnikiem tożsamości, a także podstawowym środkiem wyrazu w bezpośredniej komunikacji i prezentacji” ${ }^{22}$. Przywiązanie uwagi do wyglądu i urody w przypadku osób niewidomych jest o tyle ważne, że aspirowanie do „normalności” i społecznej akceptacji oznacza coś więcej niż tylko „zarządzanie widocznością swego piętna” - to „konieczność wypełnia-

${ }^{19}$ Tamże, s. 153.

${ }^{20}$ J. Stańczakowa, Od Autorki, [w:] tejże, Niewidoma, Warszawa 1979, s. 5.

${ }^{21}$ Zob. na ten temat M. Ładoń, dz. cyt., s. 175-177.

${ }^{22}$ K. Pietrowiak, Świat po omacku. Etnograficzne studium (nie)widzenia i (nie)sprawności, Toruń 2019, s. 266. 
nia obowiązków w zakresie właściwego i zadbanego wyglądu”"23, z których nie może zwolnić ślepota.

Stańczakowa wielokrotnie wymienia w diariuszu elementy własnego stroju: faktury tkanin, kolory, wzory, pochodzenie i opinie Mirona na ich temat. Białoszewski patrzy na przyjaciółkę z rodzajem bezwzględności i lekceważenia. Nie widzi w niej kobiety: „Jesteś stara baba, chociaż cię trajluja. I możesz nosić byle co. Nie tak? A właśnie nie tak. Starsza kobieta bardzo źle się czuje, kiedy nie jest dobrze ubrana" ${ }^{24}$. Wysiłki Jadwigi można widzieć jako próbę przeciwstawienia się tej pobłażliwej opinii, bo mimo że nie zauważa taksującego i bezwzględnego spojrzenia mężczyzny, słyszy z pewnością kpinę w jego głosie:

- Jutro Cześka umaluje mi włosy - mówię Mironowi, bo on mnie bardzo namawia. - Pomyślałem o tym w domu - powiedział któregoś dnia. - Żeby baba wiedziała, jak ją ta siwizna postarza, dawno by to zrobiła. [...]

Malowanie włosów poszło gładko. Jestem ponoć, jak przed laty, platynową blondynka. Ale jeszcze za mało. Półsiwizna ${ }^{25}$.

Moje baby mi wmawiają że jestem ładna. Nie bardzo im wierzę. Miron pokpiwa ze mnie:

- Ona przestała widzieć, kiedy była młoda, a teraz ma o sobie mylne pojęcie.

$[\ldots]$

Po długich rozterkach zdecydowałam się ostrzyc modnie. [...]

- Może być - powiedział bez entuzjazmu - ale mogłoby być więcej włosów ${ }^{26}$.

Podwójne zarządzanie kobiecościa - przez samą Stańczakową i przez Białoszewskiego - ujawnia paradoks ich relacji oraz wagę przezwyciężania kompleksu wynikającego ze ślepoty. Z jednej strony starannym doborem ubrań Stańczakowa zdaje się wychodzić naprzeciw społecznym stereotypom mówiącym o „niesamodzielności, nieatrakcyjności i aseksualności niepełnosprawnych kobiet”27. Z drugiej wszak strony - na co zwróciła już uwagę Ta-

${ }^{23}$ Tamże, s. 267. Badania etnograficzne w pełni to potwierdzają: „niewidzące kobiety interesują się sprawami związanymi z wyglądem i uroda, opowiadają o nich z zaciekawieniem, starają się odpowiednio kreować swój wizerunek, a także zachowują większą wizualną kontrolę w towarzystwie "widzących»" (tamże, s. 268).

${ }^{24}$ J. Stańczakowa, Ślepak, Warszawa 1982, s. 173.

${ }^{25}$ J. Stańczakowa, Dziennik we dwoje..., s. 88-89 (dopiski Białoszewskiego zostały w ten sposób wyróżnione przez wydawcę).

${ }^{26}$ Tamże, s. 114-115.

${ }^{27}$ K. Pietrowiak, dz. cyt., s. 271. Z jednej strony dbanie o wygląd zewnętrzny byłoby wyzwaniem rzuconym tym, którzy uważaja, że niepełnosprawność wyklucza z kobiecych standardów, z drugiej jednak - co pokazuje Maria Reimann - nieuleganie takiej presji wiązałoby się z emancypacją. „Korzystam jednak z niedowidzenia, żeby uniknąć podporządkowania się pewnym wymogom związanym z kobiecością. Czy podobnie robią niektóre dziewczyny z zespołem Turnera? Być może część osób, zamiast walczyć o wpasowanie się w sztywne normy 
tiana Czerska - to „trudny związek niewidomej kobiety z poeta, nieukrywającym przed najbliższym otoczeniem swojego homoseksualizmu"28. Z lektury Dziennika we dwoje i Tajnego dziennika Białoszewskiego wynika, jak wiele ról kobieta odgrywała wobec swojego mistrza. Czerska wymienia te funkcje: „przyjaciółki, sekretarki, asystentki, agentki, ale jednocześnie praczki, pomocy domowej, a nawet pośredniczki między Mironem a Leszkiem Solińskim" ${ }^{29}$. Przyjaźń i chęć (czy wręcz przymus) zaspokajania codziennych potrzeb mężczyzny sa tego w pewnym stopniu wytłumaczeniem, jednak wiele anegdot związanych z konkretnymi czynnościami (jak szorowanie wanny czy pranie ubrań $^{30}$ ) wzbudza zażenowanie, którego czytelnik może domyślać się też u samej pisarki:

- Miron, a majtki? Może ci potrzebne?

- Właśnie! Kup, jak najśpieszniej, bo mi pękły na dupie.

- Ale jakie?

- Takie zwyczajne, jak prześcieradło. Mogą być czerwone, jak nie ma innych. Tylko gładkie. Nieszorstkie.

- Dobra.

- Średnie, bo pewnie nie wiesz, jaki rozmiar.

$-\mathrm{Tak}^{31}$.

Te anegdotyczne, lekkie i dowcipne dialogi maja swój ciemny rewers: ujawniają nie tyle niezaradność Białoszewskiego, ile wykorzystywanie przez niego Stańczakowej i jej opiekunek (jak określał je Miron, „bab”). I to raczej one sprzeciwiają się takiej zależności, która dla Stańczakowej mogła być ekwiwalentem niemożliwej w innej formie intymności z poetą:

Wpada Miron.

- Buty ciasne, nogi mnie bolą. Kupcie mi buty.

- A sam nie możesz?

- Sprzedawczynie sa okropne. Wychodzę, potem zapominam. Kup z jakąś baba.

- Ale one nie bardzo chca.

- To od czego sa?

- Miron, one mają po siedemdziesiąt lat, też nie znoszą kolejek. I wstyd mi po prostu. Chodzą ze mna, niewidomą, a nie żeby dla widzącego buty kupować.

$-\mathrm{E}$.

- Powiem Annie. Może kupi.

dotyczące kobiecości, woli się po prostu przestać tymi normami zajmować?". M. Reimann, dz. cyt., s. 109.

${ }^{28}$ T. Czerska, dz. cyt., s. 140.

${ }^{29}$ Tamże.

${ }^{30}$ Dziennik we dwoje zawiera parodię diarystycznych zapisków Stańczakowej ze słynna już fraza „Prałam swoje majtki i majtki Mirona”. J. Stańczakowa, Dziennik we dwoje..., s. 164 .

${ }^{31}$ Tamże, s. 43. 
Potem Anna powiedziała, że też nie chce. Nałaziła się. Nie kupiła.

- Niech Miron sam kupuje albo boso chodzi ${ }^{32}$.

Wybrane partie diariusza i prozy autofikcjonalnej Stańczakowej moga ilustrować napięcie wynikające - o czym pisał Pietrowiak - ze „sprzecznych oczekiwań widzącej publiczności” wobec niewidomych, która „z jednej strony wyznacza im rolę aseksualnej, skromnej i skazanej na staropanieństwo (kobiety) niewidomej, z drugiej zaś wymaga od nich wzmożonej kontroli wyglądu, traktowanego jako miara ich normalności i atrakcyjności” ${ }^{33}$. Stańczakowa jest dyskretna i chociaż nie przemilcza całkowicie swych miłosnych i seksualnych przeżyć z młodości, z okresu „niedowidzeń”, to dotyczą one głównie przeżyć emocjonalnych ${ }^{34}$. Nie pisze z kolei o swoim małżeństwie (i jego rozpadzie) ze Zdzisławem, któremu rodzina Jadwigi zawdzięczała wyjście z getta. Jego osoba została utrwalona jakby śladowo, na marginesie - jako jednego z adoratorów przed- i wojennych. Tymczasem jego sylwetki nie można zignorować, ponieważ dzieląc po wojnie wspólne mieszkanie na Hożej, pozostawał wciąż obecny w życiu Stańczakowej. Los pisarki od początku lat pięćdziesiątych jest przedziwnie splątany: mieszka zatem z byłym mężem, pokój dzieli z córką Anna, urodzoną w 1947 roku, kolejny zajmuje niedosłyszący ojciec, nazywany w jej utworach Dziadkiem, oraz gosposia, rezydujaca za kredensem. Właściwie wszystkie persony tego układu rodzinnego wpływają na stopień (nie)zrealizowania seksualności Jadwigi:

Kiedy wróciłam do Warszawy w pięćdziesiątym drugim roku, poznałam pewnego pana. I przeżyłam miłość. Ten pan, tak jak ja, niemal całkowicie utracił wzrok. [...] Sprawa wymagała dyskrecji. Spotykaliśmy się od czasu do czasu w wypożyczonej kawalerce. Ale ponieważ żadne z nas nie mogło tam dotrzeć samodzielnie, musieliśmy mieć swoich zaufanych. Zupełnie jak w komedii - totumfacki i subretka ${ }^{35}$.

W takim właśnie tonie - komedii czy operetki komicznej - realizuje swoją opowieść Stańczakowa, jakbyśmy podglądali podejrzane schadzki. Wyjaśniając te okoliczności, pisarka dopowiada: „Dzieliłam wówczas pokój z Ania pięciolatka. A za naszymi plecami, w tak zwanym stołowym, rezydował Dziadek, mój ojciec. Dziadek niechętnie odnosił się do moich

${ }^{32}$ Tamże, s. 344. Tatiana Czerska pisała: „Kupowanie bielizny, cerowanie i prasowanie koszul to namiastka fizycznego obcowania z mężczyzną. Stańczakowa przecież nie może napisać wprost o swoich uczuciach, wszak Białoszewski na bieżąco czyta i koryguje zapiski przyjaciółki. Ten podskórny nurt dziennika, niewyrażone, nienazwane uczucie, starannie ukrywane pod maską autoironii, niekiedy przebija jednak na powierzchnię diariuszowej narracji”. T. Czerska, dz. cyt., s. 141.

${ }^{33}$ K. Pietrowiak, dz. cyt., s. 273.

${ }^{34}$ Zob. np. fragment Oni i ja w Ślepaku..., s. 101-107.

${ }^{35}$ J. Stańczakowa, Ślepak..., s. 128. 
kawalerskich wieczorów poza domem. A ja prawdę mówiąc, od dziecka trochę się go bałam"36. Dekadę później w życiu Stańczakowej pojawia się inny słabo widzący mężczyzna: „Nie mamy chaty. Spotykamy się więc od czasu do czasu u mnie przed południem. Bo to jedyna pora, kiedy z trudem mogę wykraść w moim domu dyskretną godzinę dla siebie. $\mathrm{Z}$ trudem, bo wiele przeciwności może mi stanać na drodze" ${ }^{37}$. Te trudności to oczywiście wyżej wymienione czynniki ludzkie: dyskretny, choć wyrażający „milczącą dezaprobatę" Dziadek, córka niespodziewanie wracająca do domu, wreszcie gosposia, nielicząca się z potrzebą prywatności. Trudno oczywiście wyrokować na podstawie tych oszczędnie opowiadanych perypetii uczuciowych, czy miały one szansę na rozwój. Te miłości, jak sama Stańczakowa podsumowywała, nie przetrwały, ale ważne jest dla mnie dające się wyczytać w tych zapisach napięcie między energią i szczęściem bohaterki („Biegałam na wysokich szpilkach, jakbym miała skrzydła u ramion”38) a lekceważącymi te potrzeby najbliższymi: ciężarem oceniającej obecności ojca, cieniem byłego męża w pokoju obok, na kontrolnym i nieempatycznym oku gosposi kończąc.

W zachowaniu ojca kryje się jednak coś więcej niż tylko nadopiekuńczość. Nakłada się na to jego własna niepełnosprawność, skazująca go na samotność i wykluczenie ${ }^{39}$, ciężar skrywanego żydowskiego pochodzenia, wreszcie - lęk o córkę, której ślepota zdaje się nie wykluczać z wielu form aktywności, również tych - nazwijmy je tak - kontrowersyjnych czy niecodziennych z punktu widzenia dziewięćdziesięciolatka (jak nocne wizyty i spacery z Białoszewskim). Poniższa scena (z 20 kwietnia 1975 roku) prezentuje trwanie układu osobowo-mieszkaniowego i jego konsekwencje:

W piątek była awantura z Dziadkiem (mój ojciec, lat dziewięćdziesiąt pięć). Głuchy. A ja niewidoma. Po wyjściu za mąż Ani, mojej córki, zostaliśmy sami. Nie licząc ojca Ani, mojego byłego męża, Zdzisława. Ma swoje życie. Mój pokój od Hożej. Dziadka za moimi plecami - przejściowy. Między nami część jadalno-telewizorowa. Część z oknem od podwórza to jego sypialnia. Przechodzę przez telewizorowy w kapeluszu. On mnie zatrzymuje.

- Jadziu, mam do ciebie prośbę. Taki drobiazg... żebyś nie schodziła do bramy sama.

- Będę! Muszę! - ja w pasji. - Bo znowu zachoruję! Pójdę do zakładu!

Wybiegam do sieni. Zatrzymuję się za drzwiami. Anna (nasza gosposia od ósmej do szesnastej) wrzeszczy na Dziadka:

- Po co pan jej mówił! Mówiłam, żeby nie! Ona zachoruje! [...]

${ }^{36}$ Tamże, s. 129.

${ }^{37}$ Tamże, s. 131.

38 Tamże, s. 132.

${ }^{39}$ Stańczakowa notowała w diariuszu: „Niecierpliwi mnie często, a przecież musi się, biedak, okropnie nudzić. Rozważaliśmy z Mironem, co gorsze - ślepota czy głuchota. I uznaliśmy, że głuchota, bo bardziej osamotnia”. J. Stańczakowa, Dziennik we dwoje..., s. 219. 
Cholera! Psia krew! - kipi we mnie i bulgocze. Drobiazg! Ta odrobina wolności. Kilka samotnych minut. Bez nikogo na karku. I chce mi to wydrzeć. Zawsze hamował moją samodzielnośćc ${ }^{40}$.

Obsesje i lęki seniora powoduja u Stańczakowej poczucie ograniczenia, $\mathrm{w}$ domu czuje się jak w twierdzy, a wyjścia z niego są cenzurowane. Jednocześnie jednak zapewnia mu opiekę i liczy się z jego zdaniem, mimo że w systemie wzajemnego nadzoru wciąż próbuje wygospodarować drogi ucieczek. Nie są one podyktowane kaprysami, ale głęboką potrzebą samotności i wolności - obie wartości bowiem powstrzymuja, przynajmniej na jakiś czas, nawiedzające Stańczakową fale depresji ${ }^{41}$.

\section{"Skulona"}

„Życie z niepełnosprawnością jest ciagłym nawigowaniem między poczuciem wyjątkowości - wyjątkowej niesprawiedliwości, wyjątkowej krzywdy, wyjątkowej dzielności, wyjątkowego wysiłku - a poczuciem zwyczajności, “normalności»”42 - pisze Maria Reimann. „Skulona” rodzi się właśnie w wyniku napięć między tymi rodzajami „wyjątkowości” a codziennością. To tożsamość depresyjna, której obraz przynoszą Zapiski z depresji 1980 włączone do Ślepaka, fragmenty Dziennika we dwoje i wiersze. Wewnętrzne, ślepackie ,ja” okazuje się istota o zmieniajacym się obliczu, a depresyjna twarz - elementem wyhodowanym jakby w kontrze do siebie samej. Chociaż poetka przyzwyczajona jest do własnych ciemności, to czasem natyka się na

${ }^{40}$ Tamże, s. 20-21. Maria Reimann pisze w swej książce o „ciasnej miłości”, która wychodząc od troski, lęku i konieczności zapewnienia ochrony, doprowadza do wzmocnienia, a nawet wytworzenia niepełnosprawności. M. Reimann, dz. cyt., s. 59-64. Kontrolne oko ojca nasila zatem niepełnosprawność, wpycha ponownie w stan dziecięcości i niezaradności. $\mathrm{Na}$ takie aspekty przedstawiania niepełnosprawności w powieści Jak trudno kochać Jerzego Szczygła zwracała uwagę Natalia Pamuła, Niewidzenie w powieści młodzieżowej okresu PRL na przykładzie Jak trudno kochać Jerzego Szczygła, „Kultura i Historia” 2017, nr 31.

${ }^{41}$ Samopoczucie Stańczakowej po śmierci ojca przypominało właśnie stan depresyjny. Notowała wówczas: „Od dnia pogrzebu jestem pusta. I nieludzko zmęczona. Dom zrobił się tylko mieszkaniem. Nagle za dużym. [...] Najtragiczniejsze zaczyna pomaleńku zarastać i tak troszeczkę jakby wchodzić w cień. Ale rana dopieka. I chyba w głębi zostanie. Mieszkałam z Ojcem przez pięćdziesiąt lat. Jakie będzie teraz moje życie?”; „Ciagle to bezbrzeżne zmęczenie. Życie jakby z poszarpanych urywków. Stare załazi na nowe, gmatwa się i plącze. Dziadka nie ma, a jest bardziej, niż kiedy był. Między mną a śmiercią Dziadka przelatują różne dni. Każdy oddzielny, niezłożone w żadną całość. Wiem, że się to scali i we mnie, i dokoła. Ale trzeba na to poczekać”. J. Stańczakowa, Dziennik we dwoje..., s. 282, 297. Warto dodać, że pierwszy wpis pochodzi z 20 września 1976 roku, drugi z 7 października. Czas pomiędzy został zapisany w dzienniku tylko przez Białoszewskiego.

${ }^{42}$ M. Reimann, dz. cyt., s. 76. 
obca, nierozpoznaną cząstkę, na kobietę „Skuloną”, bierna, niepodnosząca się z łóżka, otępiała. Stańczakowa rezygnuje wówczas z życia, unika ludzi; to, co wyznaczało stałe punkty odniesienia (bliscy, uporządkowane mieszkanie, rytm spacerów) staje się nieoczekiwanie obce i obojętne ${ }^{43}$. Poczucie oddzielenia i inności, wydawałoby się codzienność bohaterki, w połączeniu z różnymi kłopotami, pozornie drobnostkami, okazywało się wyjątkowo dojmujące: „Moje życie wydaje mi się tak okrutnie różne od ich [rodziny] życia. [...] Czuję się zupełnie opuszczona - po innej stronie"44. Ślepackie atuty, dowodzące wyjątkowości, ujawniały swą mroczną stronę, mimo że poetka wie, że to tylko karykaturalna zmiana proporcji, zaburzenie rzeczywistości, które zostaje zwielokrotnione przez bolesne wspomnienia z poprzednich rzutów choroby:

Więc znowu depresja. Zjazd w dół. W głąb siebie, tą czarna, jakby nieświadomość, jakby w swój cień. Trudno mówić, jakby mowa zastygła. I ciało zastyga. Trudno się zdobyć na jakikolwiek ruch. Tylko tak leżeć, leżeć... w pustce, bo w głowie zupełna pustka. I czerń dookoła, niemal fizyczna czerń.

Ale nie to najgorsze. Najgorsze, że wraca ciąg przebytych depresji ze wszystkimi szczegółami. Wszystkie męki szpitala. Agresywne chore. Kradzieże. Złe noce w gromadnej sali. Brudne klozety. Kłopoty moje, niewidomej, poruszania się wśród obcych $^{45}$.

Kuracje lekami antydepresyjnymi przynoszą oczekiwane rezultaty lecznicze, ale zmieniają energiczną Stańczakową w przygaszoną pacjentkę. Notuje w diariuszu:

Aż dziw, jak leki zmieniają człowieka. Zobojętniałam, nie denerwuje mnie dom [...].

Ta obojętność jest dobra, ale radości tak mało!

Miron powiedział:

- Łap radość za ogon. Nawet jeśli się wyrwie, zostaną ci pióra.

Usiłuję, ale to trudne. Jestem rozkojarzona, w głowie pustka. Ostatnie dni zlepiły się, został w pamięci jeden gassienicowy dzieńn ${ }^{46}$.

Osobowość Mirona okazuje się jednym z czynników aktywizujących, to na jego widok Stańczakowa gotowa jest „odrzucić apatię jak ciuch”, chociaż w gruncie rzeczy wychodzenie z depresji to walka Jadwigi ze Skulona, mozolne pozbywanie się z ramion ciężaru tej innej, w której poetka nie chce rozpoznać samej siebie. To również przekraczanie własnych granic:

Miron proponuje wycieczkę na Grochów do Celiny i Ali. Podoba mi się ten pomysł. Ale od środka denerwuję się. Po lekach latają mi ręce i nogi, więc boję się wsiadania

${ }^{43}$ O poetyckim obliczu depresji zob. M. Ładoń, dz. cyt., s. 169-173; A. Frania, dz. cyt.

${ }^{44}$ J. Stańczakowa, Ślepak..., s. 177.

${ }^{45}$ Tamże, s. 156.

${ }^{46}$ J. Stańczakowa, Dziennik we dwoje..., s. 70. 
do tramwaju i autobusu. Miron uważa, że to kompleks i trzeba go przełamać. [...] Poszło mi nie najlepiej. Wydawało mi się, że ja sobie, a moje nogi sobie. Na tych niedobrych nogach przeszłam przez tunel. Na przystanku zupełnie straciłam pewność siebie i chciałam wrócić do domu. Ale Miron zachęcił mnie do dalszej jazdy ${ }^{47}$.

Stańczakowa ów pobudzający impuls od Białoszewskiego nazywa „odkompleksieniem”, które prowadzi u niej do „poszerzenia wolności”. Po wyjściu z depresji wspomina o innej ważnej aktywności, która uwalniała ją od obecności przewodników, a zarazem - znakiem białej laski - lokowała po stronie ślepaków:

Wczoraj pierwszy raz chyba od trzech lat, bo po moich wyskokach i depresjach nigdy nie czułam się dość dobrze, wyszłam sama z białą laską na wieczorny spacer. Przemogłam się z trudem. Same wykręty, upał, zmęczenie. Ale wyszłam. Dziadek był już w łóżku. Wpół do jedenastej. Na Hożej pusto. Od murów bije ciepło. Światła w bramach. Latarnie. Dobre znaki orientacyjne. [...] Dziś dwie bramy w prawo. Dwie w lewo. Posuwam się powoli wzdłuż muru. Potem już śmielej. Dobrze. Daleki terkot tramwaju. Z rzadka suną światła samochodu. Kroki pojedynczych ludzi sypią się jak kamyki ${ }^{48}$.

Najważniejsza wydaje mi się jednak aktywność pisarska Stańczakowej. Zapiski z czasu depresji czytać należy nie tylko jako dowód na autoterapeutyczną moc słowa (przedsiębraną zresztą znów z inspiracji Białoszewskiego), ale przede wszystkim samoświadomość i dojrzałość Stańczakowej, która potrafiła wykorzystać stany psychiczne jako sposób samopoznania. Stać ja było bowiem na wyjątkowo przenikliwe i bolesne spojrzenie na siebie. Pisarka godziła się na pokazanie stanu niepokoju, na obnażenie afektów: zawiści, niechęci, zaborczości. Stany depresyjne były sygnałem, że obłaskawiona codziennością i aktywnością ciemność ma głębszy krag, w którego orbitę czasem niewidoma się dostawała. Koniec depresji roku 1980 opisała następująco: „Jadwiga górą. Zwyczajny tok życia. Tylko jeszcze ta Skulona się plącze to tu, to tam. Wieczór. Stoję w oknie okrutnie zmęczona. Ale już wyprostowana. Chce mi się żyć. Snuję różne plany. Ta depresja to nie był zmarnowany czas. Ostre spojrzenie na siebie i innych rozwiało wiele złudzeń. Ale i oświetliło dalszą drogę" ${ }^{49}$. W depresji objawiał się zatem sposób wyjścia z impasu: „- Pisałeśs - pytam. - Tak. Kilka wierszy. Zły nastrój poszedł w pisanie. Tobie też radzę - pisz dziennik. Samo formułowanie zmusza do wysiłku i przekreca uwage" ${ }^{50}$.

\footnotetext{
${ }^{47}$ Tamże, s. $70-71$.

${ }^{48}$ Tamże, s. 261.

${ }^{49}$ J. Stańczakowa, Ślepak..., s. 183.

${ }^{50}$ J. Stańczakowa, Dziennik we dwoje..., , s. 159.
} 


\section{Niewidoma pisarka}

Kiedy w 1952 roku Stańczakowa wraca z Wybrzeża do Warszawy, trafia do Polskiego Zwiazku Niewidomych i zostaje redaktorką brajlowskiego pisma „Pochodnia”. Przejście na stronę wypukłych kropek pisma brajlowskiego oznacza dla niej ważniejszy powrót - do samodzielnego czytania i pisania. Wraz z brajlowską maszyną do pisania inauguruje twórczość literacka, drukowaną na łamach brajlowskich czasopism: „Promyczka”, „Pochodni” czy „Głosu Kobiety”. W Ślepaku Stańczakowa opisuje kolejne etapy wtajemniczenia w warsztat, który mozolnie budowała i rozszerzała: o maszynę zwyczajna, nazywana „,czarnodrukowa”, potem o magnetofon, początkowo służący tylko do odsłuchiwania książek mówionych. Najważniejszy krok to pierwsze próby nagrania siebie:

W końcu pewnej nocy przemówiłam. Nienaturalnym półszeptem. Ale jednak. Opór został przełamany. [...] Kocham mój milionerski magnetofon, już dziś staromodny, z osobnym mikrofonem. Okazał się narzędziem doskonałym dla mnie, niewidomej. Zapisuję głosem prozę i wiersze. Mogę kasować, poprawiać, sprawdzać. To cudowne, zwłaszcza w wierszach. Przywróciło starą funkcję wiersza - mówienie, słuchanie wagę słowom, intonacji ${ }^{51}$.

Stańczakowa jest świadoma reguł tworzenia - nawet przepisując z magnetofonu wiersze na maszynie „czarnodrukowej”, miała poczucie budowania z klocków, układania tekstu graficznie. Co ważne, próby dziennikarskie i pisarskie nasilają się w kryzysowych momentach zagrożenia ślepota. Ciekawe, że Stańczakowa pisze „jeszcze próbuję walczyć”, mając na myśli nie kolejny zabieg operacyjny, ale pisanie sensacyjnej powieści dziennikarskiej, którą drukuje w odcinkach „Dziennik Bałtycki”. Sztuka rezygnacji z życia ze zmysłem wzroku nie oznacza dla niej rezygnacji z pisania jako takiego: „będę dziennikarką i reporterką. Tylko po niewidomemu”52, deklaruje. Dystans między dziennikarstwem a literatura pokonywała z wiara, że ślepota jest tożsama z poezją w tym znaczeniu, że obie definiują i określają własny świat, uwewnętrznione widzenie i odczuwanie. Tak jak oczy kolejnych przewodników nie mogą zastapić Stańczakowej utraconych widoków i wyglądów, tak i pamięć o widzianym z czasem blaknie, a impulsów do pisania musi szukać w ramach własnej „ciemni”. Te eksploracje wnętrza są o tyle ciekawe, że multiplikują wcielenia piszącej. Mamy zatem Jadziulkę, kilkulatkę kołysząca się z upodobaniem w hamaku i patrzącą w gwiazdy. Rekonstruując epizody z dzieciństwa, dojrzała Jadwiga zadaje pytania:

\footnotetext{
${ }^{51}$ J. Stańczakowa, Ślepak..., s. 10.

${ }^{52}$ Tamże, s. 16.
} 
Jak to jest w człowieku z dzieckiem? W starej ślepej Jadzi z tą widzącą Jadziulką? Gdzie jej szukać? Niby ani śladu. A jednak jest. I nieraz mocno daje o sobie znać. [...] Dziwię się czasami, jak bardzo potrzebna mi cisza i ciemność. [...] Więc może kołysze się we mnie ta zapatrzona w gwiazdy Jadziulka. Jest jakby trochę moim dzieckiem, trochę wizjonerskim marzeniem. Ale przy tym jest silna, bardzo silna. Potrafi mi pomóc. Kiedy napiera na mnie moje ślepe życie starej kobiety trudami, upokorzeniami, ona w jakiś sposób potrafi się wszystkiemu przeciwstawić ${ }^{53}$.

Mam wrażenie, że delikatna Jadziulka służy do rozbudowy fantazmatu tej wewnętrznej ślepoty, rodzaju oddzielenia od rówieśników, o czym Stańczakowa często pisze, jakby chciała wzmocnić znaczenie dysfunkcji poprzez traktowanie jej jak przeznaczenia. Obok Jadziulki, „Skulonej” i „podstarzałej niewidomej rencistki” jest jeszcze „Stańczakowa”- poetka ${ }^{54}$.

Późniejszy diariusz był zadaniem do wykonania zleconym przez Białoszewskiego jako rodzaj „terapii zajęciowej” w depresjach Jadwigi ${ }^{55}$. Stańczakowa w słowie wstępnym podkreśla jego „rozrywkowy wymiar”: teatralizowane czytanie, wspólne nagrywanie i odgrywanie treści, wielogłosowość, parodiowanie - wszystko czynione z inspiracji i przez Białoszewskiego. I chociaż wartość Dziennika we dwoje jest niezaprzeczalna w wielu wymiarach $^{56}$, to wyławiam z niego te treści, które w szczególny sposób poświadczaja autonomię pisarską Stańczakowej, momenty ustanawiające ją jako niezależną od mistrza poetkę. Wszelkie próby pisarskie poddawane są ocenom Białoszewskiego, zwykle surowym. Mentor zarzuca adeptce zbytnią sentymentalność, powierzchowność, nadmierną poetyckość; stawia stopnie jak uczennicy, przy tym „krzywi się” i czyta „bez entuzjazmu” ${ }^{57}$. Stańczakowa godzi się z jego decyzjami, nie polemizuje, ale ma swój moment buntu, który w kapitalnym zapisie - jest wyraźną cezurą na drodze do samostanowienia:

Nie mogę spać w nocy, to już druga noc. Zaczęłam znowu pisać wiersze. Kawałek wiersza Niedoślepłość nagrałam Mironowi, bardzo źle nagrane. Rano przyszedł Miron. Strasznie się bałam. Jakoś uznał, że nie jest taki zły. Ale potem powiedział: - Lepiej nie pisz wierszy, wolę dziennik. Do wierszy trzeba dużo pracy, dyscypliny, całe lata ćwiczeń. Jeszcze jedna baba, żeby jej zaglądać do wierszy. Byłam zła. [...] Powiedziałam mu, tak jak jest, że chcę, muszę pisać, będę próbowała. Chciałabym powiedzieć trochę o tym, jak ja niewidoma widzę świat, to znaczy taka niedoślepła właśnie. Jakie mam doznania, co czuję. Bo tego przecież nikt nie potrafi za mnie powiedzieć. A ja, czy potrafię?

Właściwie to mu wcale tak grzecznie nie powiedziałam. Powiedziałam:

- Mam cię w dupie! Chcę pisać i będę pisała. Przecież miałam swój debiut w 58 roku.

\footnotetext{
${ }^{53}$ J. Stańczakowa, Przejścia, Warszawa 1986, s. 7-8.

${ }^{54}$ Tamże, s. 202.

${ }^{55}$ Zob. J. Stańczakowa, Wstęp, [w:] tejże, Dziennik we dwoje..., s. 14.

${ }^{56}$ Zob. na ten temat A. Poprawa, dz. cyt.; T. Czerska, dz. cyt.

${ }^{57}$ Zob. J. Stańczakowa, Dziennik we dwoje..., s. 173, 310, 325, 334, 400-401.
} 
A Miron na to:

- Debiut, debiut, też znalazła referencje!58

Po wybraniu drogi poetyckiej Stańczakowa doświadcza „nocy cudów” kiedy nagrywa wypływające niejako z siebie wiersze, kiedy przerywa czynność i wraca do niej, bo nie może powstrzymać kolejnych słów. Sposób, w jaki przedstawia w dzienniku rozwój poetycki, nie przypomina odrabiania zaleconych przez mistrza zadań. Chociaż nie zmienia się jego ranga i poetce wciąż zależy na ocenie Mirona, kolekcjonuje swoje małe sukcesy: debiut na łamach „Literatury”, udział we wtorkowych spotkaniach u Białoszewskiego, gdy jej wierszy słuchają (i chwala je) Maria Janion i Małgorzata Baranowska, czy ukończenie tomiku wierszy. Od debiutu tomikiem Niewidoma w roku 1979 w dość regularnym rytmie Stańczakowa będzie pisała i wydawała książki poetyckie i prozatorskie ${ }^{59}$, korzystając wciąż z rady udzielonej przez mentora: „W drodze powrotnej mówiłam Mironowi, że nie wiem, czy mogę tak jechać na temacie ślepoty w wierszach, a on: - Oczywiście. Tylko. To ci dał Pan Bóg. Nikt tego za ciebie nie napisze. I dotychczas nie masz konkurencji”"60.

Zapętlenie losów Stańczakowej i Białoszewskiego spowodowało, że wszystkie twarze bohaterki tego tekstu kształtują się wobec niego: w oczekiwaniu na jego zdanie, akceptację, obecność, ale i w kontrze do niego. Tożsamość Stańczakowej pisarki wydaje mi się w największym stopniu autonomiczna, własna; po latach terminowania u Mirona weszła do świata literatury jako postać z własnym głosem, nawet jeśli dużo w technice pisania zawdzięczała i przejęła od nauczyciela. Jego cień oczywiście w jakimś stopniu wpływa na recepcje jej dzieł, ale coraz częściej twórczość Stańczakowej poddawana jest wielokierunkowym interpretacjom czynionym „na ukos” wobec roli Białoszewskiego i zyskuje inny status niż tylko przypis do badań nad dorobkiem autora Donosów z rzeczywistości. Anegdotyczny wymiar dziennika zadecydował, że Stańczakowa została obsadzona i zapamiętana głównie w układzie siostrzano-matczynym, w roli baby, przyjaciółki, uczennicy, opiekunki ganiającej ze swą białą laską za spodniami dla Białoszewskiego. Z innej strony - Stańczakowa, chociaż to niewątpliwie najważniejsza osoba w ostatnich latach życia Białoszewskiego, stała się też częścią jego dworu, uczestniczyła w jego życiu na prawach udziału w słuchowisku radiowym,

${ }^{58}$ Tamże, s. 309. Stańczakowa wspomina tutaj swój debiut na łamach „Promyczka”.

${ }^{59}$ Kolejno ukazały się tomy: Niewidoma, Warszawa 1979; Ślepak, Warszawa 1982; Magia niewidzenia, Warszawa 1984; Depresje i wróżby, Warszawa 1984; Przejścia, Warszawa 1986; Na żywo, Warszawa 1987; Boicie się czarnego ptaka?, Warszawa 1989; Ziemia-kosmos, Warszawa 1990; Kabaret Kizi-Mizi, Warszawa 1991; Refugium, Warszawa 1991; Japońska wiśnia. Haiku dla Michi Tsukada; Warszawa 1992; Kabaret Kizi-Mizi w locie, Warszawa 1992; Dziennik we dwoje, Warszawa 1992, drugi tom - 1994; Odwieczne drzewo, Warszawa 1995.

${ }^{60}$ J. Stańczakowa, Dziennik we dwoje..., s. 421. 
raczej głosu, a nie ciała, które się omija (również dosłownie, żeby nie spowodować kolizji z niewidzacca), a jego potrzeby wypiera. Skonfrontowane z twórczością Stańczakowej studia nad niepełnosprawnością czy badania (auto)etnograficzne pozwalają - jak sądzę - zobaczyć jej tożsamości w ramach uwarunkowań rodzinno-towarzyskich, które miały decydujacy wpływ na warianty kobiecości, seksualności i sposoby ich tekstowej reprezentacji. Wyraźny jest tutaj splot niepełnosprawności i płci: cielesność Stańczakowej nie jest wszakże pozbawiona cech seksualnych, ale musi realizować się w ramach dysfunkcji, przekraczać jej ograniczenia, wmawianą niezaradność, wygodna dla innych zależność. Co ciekawe, samodzielność poetki nie jest tożsama z dążeniem do zniwelowania niepełnosprawności - ani w aspekcie medycznym, ani w aspekcie społeczno-kulturowym. Przeciwnie, jej autonomia jako kobiety i pisarki fundowana jest właśnie na ślepocie.

\section{BIBLIOGRAFIA}

Czerska T., Dzienniki podwójne, czyli o kanibalizmie $w$ diarystyce (Michait $i$ Jelena Bułhakowowie, Jadwiga Stańczakowa i Miron Białoszewski), [w:] tejże, Diarystki: tekst $i$ egzystencja, Szczecin 2018.

Fidowicz A., Niepetnosprawność w najnowszej polskiej prozie dla młodzieży. Między ableizmem a idolatria, „Fragile” 2017, nr 1 (35).

Frania A., „Nie widzę i opisuję. Refleksje o twórczości Jadwigi Stańczakowej, „Inter-. Literatura - Krytyka - Kultura" 2018, nr 317, <https://pismointer.wordpress.com/ numery-archiwalne/nr-317-2018/arkadiusz-frania-nie-widze-i-opisuje-refleksje-o-wierszach-jadwigi-stanczakowej/> [dostęp: 2.06.2020].

Galant A., Literatura z niepetnosprawnościami. Zarys możliwych lektur, „Czas Kultury” 2019, nr 4.

Hańderek J., Niepetnosprawność?, „Fragile” 2017, nr 1 (35).

Kacperczyk A., Autoetnografia - technika, metoda, nowy paradygmat? O metodologicznym statusie autoetnografii, „Przegląd Socjologii Jakościowej” 2004, nr 10.

Kopkiewicz A., Sprawy babskie i ślepackie, „Dwutygodnik” 2015, nr 11 (172), <https:// www.dwutygodnik.com/artykul/6240-sprawy-babskie-i-slepackie.html> [dostęp: 2.06.2020].

Ładoń M., „Ćwiczę widzenie”. O twórczości Jadwigi Stańczakowej, „Poznańskie Studia Polonistyczne". Seria Literacka 32 (52), Poznań 2018.

Markiewicz M., Niepetno(s)prawni. Gdzie kończy się definicja Człowieka?, „Fragile” 2017, nr 1 (35).

Pamuła N., Niewidzenie w powieści młodzieżowej okresu PRL na przyktadzie Jak trudno kochać Jerzego Szczygta, „Kultura i Historia” 2017, nr 31.

Parę osób, mały czas, reż. A. Barański, 2005.

Pietrowiak K., Świat po omacku. Etnograficzne studium (nie)widzenia i (nie)sprawności, Toruń 2019. 
Poprawa A., Posłowie, [w:] J. Stańczakowa, Dziennik we dwoje, Wrocław 2015.

Reimann M., Nie przywitam się z państwem na ulicy. Szkic o doświadczeniu niepetnosprawności, Wołowiec 2019.

Sobolewski T., Jadwiga Stańczakowa, pisarka, „Wysokie Obcasy” (dodatek do „Gazety Wyborczej”), 28.06.2006, nr 4, <https://www.wysokieobcasy.pl/wysokie-obcasy/1,96856,3132212.html> [dostęp: 2.06.2020].

Stańczakowa J., Boicie się czarnego ptaka?, Warszawa 1989.

Stańczakowa J., Depresje i wróżby, Warszawa 1984.

Stańczakowa J., Dziennik we dwoje, Wrocław 2015.

Stańczakowa J., Haiku, Wrocław 2015.

Stańczakowa J., Japońska wiśnia. Haiku dla Michi Tsukada, Warszawa 1992.

Stańczakowa J., Kabaret Kizi-Mizi w locie, Warszawa 1992.

Stańczakowa J., Kabaret Kizi-Mizi, Warszawa 1991.

Stańczakowa J., Magia niewidzenia, Warszawa 1984.

Stańczakowa J., Na żywo, Warszawa 1987.

Stańczakowa J., Niewidoma, Warszawa 1979.

Stańczakowa J., Odwieczne drzewo, Warszawa 1995.

Stańczakowa J., Przejścia, Warszawa 1986.

Stańczakowa J., Refugium, Warszawa 1991.

Stańczakowa J., Ślepak, Warszawa 1982.

Stańczakowa J., Ziemia-kosmos, Warszawa 1990.

Stańczakowa sama i z Mironem [skrócony zapis rozmowy Anny Sobolewskiej, Justyny Sobolewskiej, Joanny Mueller-Liczner i Elizy Kackiej], <https://kulturaliberalna. pl/2015/09/08/stanczakowa-sama-i-z-mironem-skrocony-zapis-rozmowy/> [dostęp: 2.06.2020].

Świerkosz M., Stwarzanie niepetnosprawnego ciała. Kilka uwag o performatywnej teorii i praktykach teatralnych, „Czas Kultury” 2019, nr 4.

Zdanowska M., Nie-złe upośledzenie, „Znak” 2017, nr 740.

Zdrodowska M., Między aktywizmem a akademiq. Studia nad niepetnosprawnościa, „Teksty Drugie” 2016, nr 5. 
